\title{
Pengaruh jenis adsorben terhadap purifikasi biogas sistem kontinu
}

\author{
Angga Pangestu ${ }^{*}$, Dwi Irawan ${ }^{2}$, Kemas Ridhuan $^{3}$ \\ ${ }^{1}$ Prodi Magister Teknik Mesin, Fakultas Teknik, Universitas Muhammadiyah Metro \\ Jl. Ki Hajar Dewantara 15 A Kota Metro, Lampung, Indonesia \\ ${ }^{2,3}$ Jurusan Teknik Mesin, Fakultas Teknik, Universitas Muhammadiyah Metro \\ Jl. Ki Hajar Dewantara 15 A Kota Metro, Lampung, Indonesia \\ *Corresponding author: anggapangestu123@yahoo.com
}

\begin{abstract}
Abstrak
Energi merupakan suatu hal penting untuk menunjang kehidupan manusia, dengan banyaknya kebutuhan maka perlu dilakukan pembaharuan tentang energi salah satu nya energi terbarukan. Biogas merupakan salah satu energi terbarukan yang dapat digunakan sebagai pengganti energi fosil. Kemurnian biogas yang dihasilkan dari digester belum optimal sehingga perlu dilakukan purifikasi untuk meningkatkan kandungan metana dan menurunkan kandungan karbondioksida. Tujuan dari penelitian ini adalah untuk mengetahui pengaruh jenis adsorben terhadap kandungan metana dan kandungan karbondioksida. Metode yang digunakan dalam penelitian ini menggunakan metode adsorpsi dan menggunakan dua tabung adsorben susunan seri yang berisi zeolit dengan zeolit, zeolit dengan karbon aktif dan zeolit dengan geram besi. Dari hasil penelitian saat sebelum dilakukan purifikasi kandungan metana $6088 \mathrm{ppm}$ dan kandungan karbondioksida 15927,6 ppm, sedangkan setelah dilakukan purifikasi terdapat perbedaaan pada masing-masing adsorben yaitu zeolit dan zeolit 26750,6 ppm dan 5333,2 ppm, zeolit dengan karbon aktif 18621,2 ppm dan 8331,1 ppm, dan zeolit dengan geram besi 12368,4 ppm dan 10718,3 ppm. Penggunaan adsorben zeolit dan zeolit mengalami peningkatan kandungan metana tertinggi yaitu meningkat 20662,6 ppm dari sebelum dilakukan purifikasi dan kandungan karbondioksida menurun sebesar 10594,4 ppm dari sebelum dilakukan purifikasi.
\end{abstract}

Kata kunci: Adsorben, purifikasi, biogas, zeolit, karbon aktif, geram besi

\section{Pendahuluan}

Biogas merupakan sebuah energi alternative yang dapat dimanfaatkan sebagai pengganti energi fosil yang kegunaannya dapat dimanfaatkan sebagai pembangkitan panas, listrik dan masih banyak lagi kegunaanya yang dapat dimanfaatkan. Biogas juga mempunyai banyak kelebihan yaitu tidak akan pernah habis, murah, efisien, dan lebih ramah lingkungan. Limbah industry makanan, sisa-sisa makanan, dan kotoran ternak dapat dimanfaatkan dalam pembuatan biogas.

Secara prinsip dalam pembuatan biogas sangat sederhana yaitu dengan memasukkan substrat yang berupa limbah organik, sisa-sisa makanan, atau kotoran ternak ke dalam digester kemudian ditutup rapat dan beberapa waktu akan terbentuk gas yang dapat digunakan sebagai sumber energi. Kandungan biogas pada umumnya terdiri dari beberapa gas metana $\left(\mathrm{CH}_{4}\right) 50$ $70 \%$, gas karbondioksida $\left(\mathrm{CO}_{2}\right)$ 30-40\%, gas hydrogen $\left(\mathrm{H}_{2}\right) \quad 5-10 \%$ dan sisanya berupa gas lain. Nilai pembakaran gas metana murni dapat mencapai $8900 \mathrm{kkal} / \mathrm{m}^{3}$ sedangkan yang terdapat pada biogas nilai panas pembakaran hanya 4800-6200 $\mathrm{kkal} / \mathrm{m}^{3}$, ini menunjukkan bahwa nilai ini lebih rendah dari gas metana murni [1].

Gas metana $\left(\mathrm{CH}_{4}\right)$ dan gas karbondioksida $\left(\mathrm{CO}_{2}\right)$ merupakan unsur yang sangat berperan terhadap nilai kalor yang dihasilkan, jika kadar $\mathrm{CH}_{4}$ tinggi maka biogas memiliki nilai kalor yang tinggi tetapi jika kadar $\mathrm{CO}_{2}$ yang tinggi maka nilai kalor akan rendah sehingga keberadaan $\mathrm{CO}_{2}$ dalam gas $\mathrm{CH}_{4}$ sangat tidak diinginkan. 
Banyak sekali upaya dalam pengoptimalan biogas yaitu salah satunya dengan cara metode adsorpsi.

Adsorpsi adalah salah satu metode dalam proses purifikasi/pemurnian biogas yang dilakukan dengan terjadinya suatu peristiwa aliran fluida yang terjadi kontak dengan suatu padatan sehingga fluida tersebut akan mengalami perubahan komposisi. Adsorpsi bertujuan untuk meningkatkan nilai kandungan $\mathrm{CH}_{4}$ yaitu dengan menyerap gas pengotor. Umumnya dalam adsorben menggunakan material yang berpori terutama pada letak tertentu dalam partikel. Adsorben padat yang memiliki potensi dalam memurnikan metana $\mathrm{CH}_{4}$ adalah karbon aktif, zeolit dan besi oksidasi.

$$
\text { Zeolit merupakan senyawa }
$$

aluminosilikat tehidrasi yang memiliki ikatan $\mathrm{SiO}_{4}$ dan $\mathrm{AlO}_{4}$ tetrahidra yang sangat berhubungan dengan atom sehingga membentuk kerangka. Pada kerangka zeolit, tiap atom $\mathrm{Al}$ bersifat negative dan akan dinetralkan oleh ikatan kation yang mudah dipertukarkan yang akan berpengaruh dalam proses adsorpsi dan sifat sifat thermaslzeolit [2]. Kemampuan adsorpsi pada zeolit banyak dipengaruhi oleh beberapa factor yaitu adanya perbandingan $\mathrm{Si} / \mathrm{Al}$ dan geometri pori-pori zeolit, luas permukaan dalam, dsitribusi ukuran pori dan bentuk pori [3]. Zeolit lokal yang terdapat di Lampung ada di daerah Lampung Selatan, zeolit ini sangat berpotensi sebagai adsorben dalam pemurnian biogas.

Karbon aktif merupakan salah satu adsorben yang dapat digunakan sebagai pemurnian gas. Karbon aktif memiliki struktur pori-pori internal dan juga memiliki luas permukaan berkisar antara 300-2000 $\mathrm{m}^{2} / \mathrm{g}$ hal tersebut yang menyebabkan karbon aktif mempunyai sifat sebagai adsorben. Daya serap karbon aktif sangat besar, yaitu 25-100\% terhadap berat karbon aktif [4].

Penelitian ini bertujuan untuk mengetahui berapa nilai kadar $\mathrm{CO}_{2}$ yang diturunkan pada biogas dengan menggunakan beberapa jenis adsorben dalam upaya meningkatkan kemurnian dan mengetahui kandungan $\mathrm{CH}_{4}$ sehingga dapat menambah nilai kalor yang tinggi dengan cara memvariasi dari beberapa jenis adsorben yaitu karbon aktif, zeolit dan besi oksidasi. Biogas yang digunakan merupakan biogas sistem kontinu yaitu biogas yang dibuat secara terus menerus

\section{Tinjauan Pustaka}

\section{Biogas}

Biogas adalah sumber energi alternative yang dapat digunakan sebagai pengganti bahan bakar sumber energi fosil. Biogas merupakan gas yang terbentuk karena proses fermentasi anaerob senyawa organik seperti limbah rumah tangga, kotoran manusia, atau kotoran hewan.

Faktor-faktor pembuatan biogas menurut Wahyuni (2013) antara lain Substrat bahan organic, Kandungan total solid, Drajad kemasaman $\mathrm{pH}$, Nisbah $\mathrm{C} / \mathrm{N}$, suhu, pengadukan [5].

\section{Purifikasi}

Purifikasi adalah sebuah proses pemisahan suatu hal tertentu dari hal lain yang tidak diinginkan sehingga mendapatkan suatu kemurnian. Biogas terdapat beberapa kandungan yang ada yaitu $\mathrm{CH}_{4}, \mathrm{CO}_{2}, \mathrm{~N}_{2}, \mathrm{H}_{2}$ dan $\mathrm{H}_{2} \mathrm{~S}$ sedangkan dari semua unsure kandungan tersebut, gas metana $\left(\mathrm{CH}_{4}\right)$ dan karbondioksida $\left(\mathrm{CO}_{2}\right)$ merupakan unsur yang paling sangat mempengaruhi nilai kalor yang dihasilkan [6].

\section{Adsorpsi}

Adsorpsi adalah salah satu metode untuk melakukan purifikasi/pemurnian biogas untuk meningkatkan nilai kalor, adsorbsi merupakan suatu proses dimana molukel-molekul fluida (gas maupun cairan) yang menyentuh dan melekat pada permukaan padatan [7]. Dalam proses adsorpsi ini maka adanya suatu material yang berperan penting untuk mengikat molekul-molekul fluida tersebut, material ini memiliki pori terutama pada letak tertentu dalam partikel. Banyak macam material yang memiliki potensi sebagai 
adsorben yakni Zeolit, Karbon Aktif, Besi Oksidasi, dan masih banyak lagi.

\section{Zeolit}

Zeolit merupakan salah satu jenis adsorben yang dapat digunakan sebagai purifikasi biogas yang dapat mengikat $\mathrm{CO}_{2}$ sehingga dapat meningkatkan performa biogas. Penggunaan zeolit sebagai adsorben maka akan meningkatkan nilai kalor karena zeolit akan menyerap gas-gas yang dapat menurunkan nilai kalor tanpa menyerap gas utama nya yaitu metana. Zeolit merupakan senyawa aluminosilikat terhdrasi yang terdiri dari ikatan $\mathrm{SiO}_{4}$ dan $\mathrm{AlO}_{4}$ tetrahidra yang dihubungkan oleh atom oksigen untuk membentuk kerangka. Pada kerangka Zeolit, tiap atom Al bersifat negative dan akan di netralkan oleh ikatan dengan kation yang mudah dipertukarkan yang berpengaruh dalam proses adsorpsi dan sifat-sifsat thermal zeolite [2].

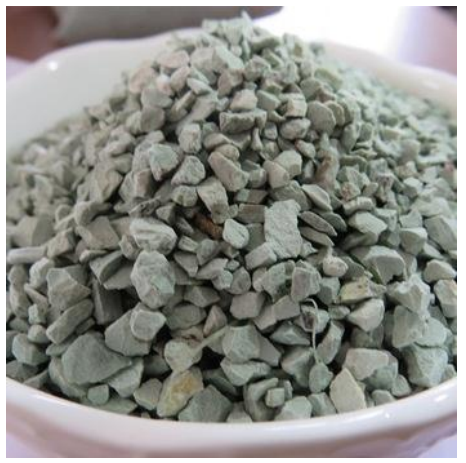

Gambar 1. Zeolit

\section{Karbon aktif}

Karbon aktif sangat berpotensi sebagai adsorben yang dapat memurnikan biogas sehingga kalor pada biogas akan meningkat, luas permukaan karbon aktif berkisar antara 300 sampai $2000 \mathrm{~m}^{2} / \mathrm{g}$. Hal tersebut berhubungan dengan struktur poripori internal yang menyebabkan karbon aktif mempunyai sifat sebagai adsorben. Karbon aktif dapat mengadsorpsi gas dan senyawa-senyawa kimia tertentu atau sifat adsorpsinya selektif bergantung pada besar atau volume pori-pori dan luas permukaan. Daya serap karbon aktif sangat besar, yaitu 25-100\% terhadap berat karbon aktif [4].

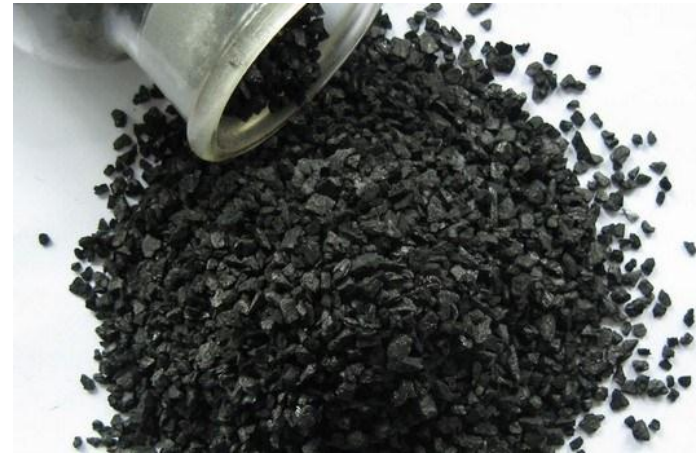

Gambar 2. Karbon aktif

\section{Geram besi}

Merupakan limbah sisa pembubutan yang mempunyai senyawa oksida dari besi dan mempunyai rumus kimia $\mathrm{Fe}_{2} \mathrm{O}_{3}$ dan mempunyai sifat paramagnetic. Dalam proses pemurnian biogas $\mathrm{Fe}_{2} \mathrm{O}_{3}$ berfungsi sebagai pengikat gas $\mathrm{H}_{2} \mathrm{~S}$ [8].

Salah satu untuk mendapatkan $\mathrm{Fe}_{2} \mathrm{O}_{3}$ dari limbah geram besi atau serpihan besi yang diperoleh dari limbah pembubutan logam besi/baja, limbah geram besi ini biasanya dicairkan kembali, namun karena proses pembubutan itu sendiri terjadi pada suhu tinggi maka sebenarnya sudah merupakan hasil reaksi antara besi dengan oksida sehingga jika dicairkan kembali maka hasilnya tidak akan baik seperti logam aslinya, limbah geram besi dari proses pembubutan tersebut kemudian dilakukan proses pelunakan (annealing) dengan membakar gram besi tersebut pada suhu $900^{\circ} \mathrm{C}$ sampai gram besi terlihat merah membara kemudian dibiarkan menjadi dingin secara perlahan didalam tungku. Proses oksidasi terjadi pada proses pelunakan ini menghasilkan $\mathrm{Fe}_{2} \mathrm{O}_{3}$ dan juga $\mathrm{Fe}(\mathrm{OH})_{3}[9]$.

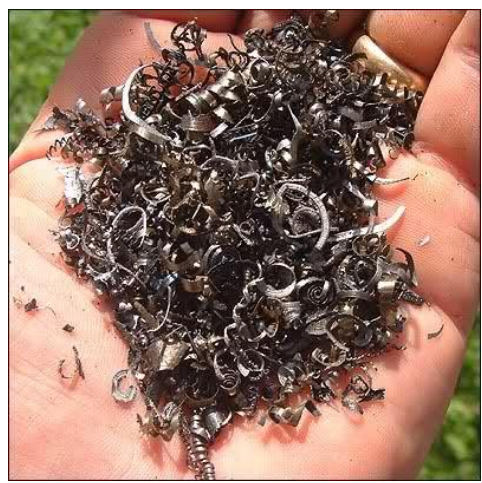

Gambar 3. Gram besi 


\section{Metode Penelitian}

Untuk mendapatkan hasil dari Pengaruh Jenis Adsorben Terhadap Purifikasi Biogas Sistem Kontinu, adapun langkah-langkahnya sebagai berikut:

a. Biogas sistem kontinu dari kotoran sapi dengan perbandingan 1:1.

b. Peneliatian ini dilakukan dengan memvariasikan adsorben yang ada yaitu: zeolit, karbon aktif, dan besi oksidasi

c. Variasi yang dilakukan sebnyak 3 kali yaitu, Zeolit dengan zeolite, Zeolit dengan karbon aktif dan Zeolit dengan Geram Besi

d. Menyediakan alat purifikasi yang sudah dibuat

e. Buka katup agar aliran biogas dari digester akan mengalir melalui pipa yang akan menuju ke tiap tiap tabung adsorben yang sudah disiapkan.

f. Ketika katup valve sudah dibuka maka biogas akan mengalir, saat biogas mengalir maka akan terbaca oleh alat sensor gas MQ2 kemudian disalurkan ke laptop sehingga nilai kandungan yang ada pada biogas terbeut akan tertera di aplikasi arduino.

g. Kemudian catat hasil pengujian tersebut ke dalam tabel

\section{Hasil dan Pembahasan}

Hasil dari pengaruh jenis adsorben terhadap kandungan metana pada purifikasi biogas sebagai berikut:

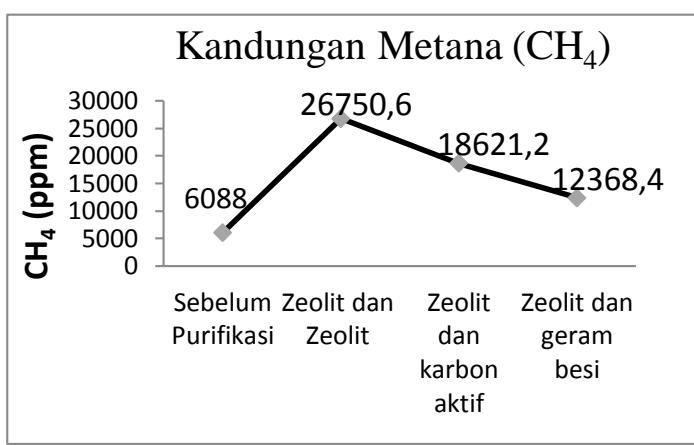

Gambar 4. Grafik pengaruh media adsorben terhadap kandungan metana
Dari Gambar 4 menunjukkan bahwa kandungan metana saat sebelum dilakukan purifikasi yaitu memiliki nilai kandungan metana yang sangat rendah yaitu hanya 6088 ppm, ini dikarenakan biogas tersebut belum dilakukan pemurnian/purifikasi terlebih dahulu.

Purifikasi yang menggunakan adsorben zeolit dengan zeolit mempunyai kandungan metana yaitu sebesar 26750,6 ppm. Hasil kandugan metana pada biogas yang dilakukan purifikasi zeolit dengan zeolit mengalami peningkatan yang sangat tinggi yaitu naik sampai 20662,6 ppm dari sebelum dilakukannya purifikasi.

Dari hasil tersebut menyatakan bahwa penggunaan zeolit sebagai purifikasi ini disebabkan karena zeolit memiliki poripori yang berukuran molekuler sehingga mampu memisahkan atau menyaring molekul dengan ukuran tertentu dan zeolit mempunyai kapasitas tukar kation yang tinggi hal ini sesuai dengan penelitian Wahono (2010) yang menyatakan bahwa zeolit memiliki kemampuan untuk meningkatkan biogas karena mempunyai selektivitas yang tinggi dan mampu menyerap semua gas pengotor utama yaitu $\mathrm{CO}_{2}$ dan $\mathrm{H}_{2} \mathrm{~S}$ namun tidak menyerap gas utama yang dimurnikan yaitu $\mathrm{CH}_{4}$ [10].

Kandungan metana pada purifikasi dengan menggunakan zeolit dan karbon aktif yaitu sebesar 18621,2 ppm dan mengalami peningkatan sebesar 12533,2 ppm dari sebelum purifikasi. Peningkatan dengan menggunakan adsorben zeolit dan karbon aktif yang terjadi tidak setinggi adsorben variasi zeolit dengan zeolit, ini dikarenakan dalam purifikasi dengan menggunakan karbon aktif yang sangat mempengaruhi daya serap adsorpsi yaitu dengan luas permukaannya karena semakin besar luas permukaannya maka kapasitas adsorpsi akan tinggi hal ini sesuai dengan penelitian Suzuki (2010) yang menyatakan bahwa semakin luas permukaan spesifik adsorben maka kemampuan adsorpsi akan semakin meningkat [11].

Sedangkan purifikasi dengan menggunakan variasi zeolit dengan gram 
besi hanya 12368,4 ppm dan mengalami peningkatan sebesar 6280,4 ppm dengan sebelum di purifikasi. Dibandingkan dengan variasi zeolit dengan zeolit dan variasi zeolit dengan karbon aktif penggunaan adsorben zeolit dengan gram besi sebagai purifikasi dalam upaya peningkatan kandungan metana lebih kecil, ini dikarenakan penggunaan gram besi hanya baik dalam memurnikan gas $\mathrm{H}_{2} \mathrm{~S}$ tetapi dalam peningkatan metana kurang baik hal ini sesuai dengan penelitian Kertamus (2004) yang menyatakan bahwa besi oksida dalam bahan adsorben hanya memurnikan gas $\mathrm{H}_{2} \mathrm{~S}$ [12].

Dari hasil tersebut maka yang dapat dilihat bahwa penggunaan purifikasi sangat lah penting dalam peningkatan kandungan metana. Peningkatan kandungan metana yang tinggi yaitu dengan penggunaan adsorben variasi zeolit dengan zeolite.

Hasil dari Pengaruh Jenis Adsorben Terhadap Kandungan Karbondioksida Pada Purifikasi Biogas di dapat sebagai berikut

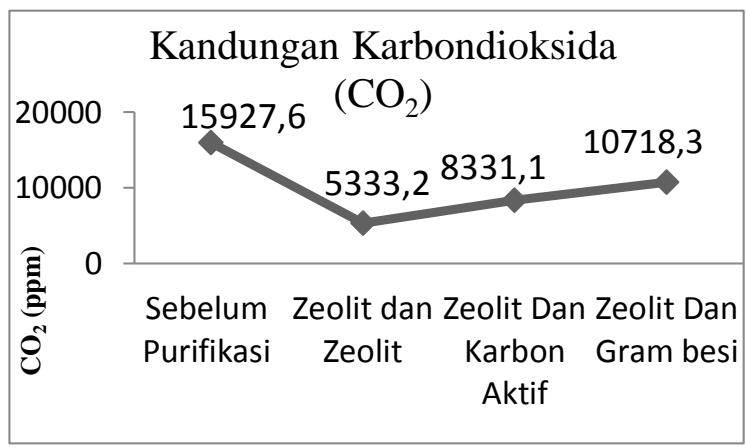

Gambar 5. Grafik pengaruh media adsorben terhadap kandungan karbondioksida $\left(\mathrm{CO}_{2}\right)$.

Karbondioksida merupakan gas pengotor yang dapat mempengaruhi nilai kalor, karena semakin tinggi karbondioksida maka semakin rendah nilai kalornya begitu juga sebaliknya jika karbondioksida rendah maka nilai kalor akan tinggi. Dari grafik diatas kandungan karbondioksida saat sebelum purifikasi yaitu sebesar 15927,6 ppm. Sedangkan biogas yang dipurifikasi dengan menggunakana adsorben variasi zeolit dengan zeolit sebesar 5333,2 ppm dan mengalami penurunan mencapai 10594,4 ppm. Selain meningkatkan kandungan metana, zeolit juga mampu untuk meyerap karbondioksida sehingga karbondioksida pada biogas akan berkurang.

Penurunan karbondioksida pada adsorben zeolit ini karena polaritas yang dimiliki $\mathrm{CO}_{2}$ dimana atom $\mathrm{O}$ dengan muatan negative cenderung mendonorkan muatan kation-kation zeolit yang bermuatan positif pada permukaan zeolit dan sesuai dengan penelitian dari Solikah (2014) yang menyatakan bahwa struktur zeolit yang berongga sehingga mampu menyerap sejumlah besar molekul yang berukuran lebih kecil atau sesuai dengan ukuran rongganya [13].

Purifikasi biogas menggunakan adsorben variasi zeolit dengan karbon aktif mencapai 8331,1 ppm dan mengalami penurunan 7596,5 ppm saat sebelum purifikasi.Penurunan karbondioksida disebabkan karena karbonaktif memiliki sifat adsorpsinya yang selektif bergantung pada besar atau volume pori-pori dan luas permukaan pada karbonaktif sesuai dengan penelitian Ritonga (2017) yang menyatakan karbon aktif yang bersifat hidrofob dan nonpolar yang mampu mengikat karbon [6].

Sedangkan purifikasi menggunakan adsorben variasi zeolit dengan gram besi hanya mencapai 10718,3 ppm dan mengalami penurunan karbondioksida 5209,3 ppm dengan sebelum purifikasi. Penggunaan adsorben gram besi sebagai penurunan kandungan karbondioksida yang tidak cenderung besar dibandingkan dengan variasi lainnya ini dikarenakan gram besi memiliki rekasi kimia $\mathrm{Fe}_{2} \mathrm{O}_{3}$ yang sangat baik dalam memurnikan $\mathrm{H}_{2} \mathrm{~S}$ hal ini sesuai dengan penelitian Negara (2012) bahwa penurunan gas pengotor disebabkan karena gram besi telah mengalami proses oksidasi menjadi besi oksida yang dilakukan proses pelunakan sebelumnya [9].

Dari hasil tersebut maka dapat dilihat bahwa penggunaan adsorben variasi zeolit dengan zeolitlah yang sangat baik dalam penurunan kandungan karbondioksida, sehingga nilai kalor pada biogas dapat meningkat. 


\section{Kesimpulan}

Dari hasil pengujian yang sudah dilakukan maka didapat kesimpulan bahwa kandungan metana yang ada pada biogas saat sebelum di purifikasi yaitu rata-rata 6088 ppm sedangkan kandungan metana pada biogas yang dilakukakan purifikasi dengan menggunanan variasi zeolit dengan zeolit rata-rata 26750,6 ppm, variasi zeolit dengan karbon aktif rata-rata 18621,2 ppm, dan menggunakan zeolit dengan gram besi rata-rata 12368,4 ppm. Penigkatan tertinggi terjadi pada purifikasi dengan menggunakan variasi zeolit dan zeolit yaitu meningkat sebesar 20662,6 ppm. Saat sebelum dilakukannya purifikasi biogas kandungan karbondioksida yang ada rata-rata sebesar 15927,6 ppm sedangkan kandungan karbondioksida saat sudah dilakukan purifikasi menurun. Purifikasi dengan adsorben zeolit dan zeolit rata-rata sebesar 5333,2 ppm, purifikasi dengan zeolit dan karbon aktif 8331,1 ppm, purifikasi dengan zeolit dan gram besi 10718,3 ppm. Penurunan karbondioksida tertinggi terjadi pada purifikasi dengan menggunakan variasi zeolit dan zeolit yaitu meningkat sebesar 10594,4 ppm.

\section{Referensi}

[1] Mara, M. (2012). Analisis Penyerapan Gas Karbondioksida (CO2) Dengan Larutan $\mathrm{NaOH}$ Terhadap Kualitas Biogas Kotoran Sapi. Dinamika Teknik Mesin: Jurnal Keilmuan dan Terapan Teknik Mesin, 2(1).

[2] Çakıcğlu-Ozkan, F., \& Ülkü, S. (2008). Diffusion mechanism of water vapour in a zeolitic tuff rich in clinoptilolite. Journal of thermal analysis and calorimetry, 94(3), 699702.

[3] Gruszkiewics, M.S., Simonson, J.M., Burchell, T.D., Cole, D.R., 2005, Water Adsorption and Desorption on Microporous Solids at Elevated Temperature, Journal of Thermal Analysis and Calorimetry 81, 609615.
[4] Arifin. (2010). Dekolorisasi Air yang Mengandung Zat Pewarna Tekstil dengan Metode Koagulasi Poly Almunium Chloride dan Adsorpsi Karbon aktif. Tangerang: PT Tirta Kencana Cahaya Mandiri.

[5] Wahyuni, S., \& MP, S. (2013). Biogas: Energi Alternatif Pengganti BBM, Gas dan Listrik. AgroMedia.

[6] Ritonga, A. M., \& Masrukhi, M. (2017). Optimasi Kandungan Metana (CH4) Biogas Kotoran Sapi Menggunakan Berbagai Jenis Adsorben. Rona Teknik Pertanian, 10(2), 11-22.

[7] Nasruddin., 2005. Dynamic Modeling and Simulation of a Two-Bed Silicagel-Water Adsorpstion Chiller (Disertation). Germany: Rwth Aachen.

[8] Dienullah, M., Tira, H. S., \& Padang, Y. A. (2018). Pemurnian Biogas Dengan Sistem Berlapis Menggunakann Fe2o3, Zeolit Sintetik Dan Zeolit Alam. Jurnal Ilmiah Teknik Mesin, 15(1), 1-8.

[9] Negara, K. M. T., Nindhia, T. G. T., Sucipta, I. M., Atmika, I. K. A., Negara, D. N. K. P., Surata, I. W., \& Komaladewi, A. S. (2012). Pemurnian Biogas dari Gas Pengotor Hidrogen Sulfida (H2S) dengan Memanfaatkan Limbah Geram Besi Proses Pembubutan. Jurnal Energi dan Manufaktur, 5(1).

[10] Wahono, S. K., Maryana, R., Kismurtono, M., Kismurtono, M., \& KNisa, K. (2010). Modifikasi Zeolit Lokal Gunungkidul Sebagai Upaya Peningkatan Performa Biogas Untuk Pembangkit Listrik.

[11] Suzuki, Motoyuki. 1990. Adsorption Engineering. Kodansha Ltd. Tokyo.

[12] N.J. Kertamus., 2004, Removal of $\mathrm{H}_{2} \mathrm{~S}$ on Oxidized Iron; 131-158.

[13] Solikah, S., \& Utami, B. (2014, June). Perbedaan Penggunaan Adsorben Dari Zeolit Alam Teraktivasi dan Zeolit Terimmobilisasi Dithizon Untuk Penyerapan Ion Logam 
Tembaga (Cu. In Seminar Nasional

Kimia dan Pendidikan Kimia VI.

Surakarta (Vol. 21). 